\title{
Level of Cytokines at Teenagers against the Background of Lambliasis Invasia
}

\author{
T. I. Ryabichenko1, A. N. Trunov1, G. A. Skosyreva1, E. P. Timofeeva², \\ T. V. Kartseva ${ }^{2}$, T. G. Kosianova ${ }^{1}$ \\ ${ }^{1}$ Scientific Centre of Clinical and Experimental Medicine, Siberian Branch of Russian Academy of Medical \\ Science, Novosibirsk, Russia \\ ${ }^{2}$ Novosibirski State Medical University of the Ministry of Health of Russia, Moscow, Russia \\ Email: irkind2010@gmail.com
}

Received 5 May 2014; revised 5 June 2014; accepted 12 June 2014

Copyright (C) 2014 by authors and Scientific Research Publishing Inc.

This work is licensed under the Creative Commons Attribution International License (CC BY).

http://creativecommons.org/licenses/by/4.0/

c) (7) Open Access

\begin{abstract}
The cytokines' levels of pro-inflammatory and anti-inflammatory activity, levels of lactoferrin, of the circulating immune complexes and the level of antibodies to antigens of the native deoxyribonucleic acid (DNA) are investigated. The purpose of investigation was to study the pathogenic features of clinical course of chronic lambliasis invasia at teenagers. The statistically significant hypercitokinemia owing to the pro-inflammatory and anti-inflammatory cytokines with the highest concentration of IL-1 $\beta$, IL-4, the high level of lactoferrin-protein of acute phase, the occurrence of markers of cellular damage, the high level of immune complexes and the stimulation of humoral link of immune system, the high level of antibodies to the antigen of native DNA, are registered. The obtained data may be used as additional diagnostic criteria of lambliasis invasia at teenagers.
\end{abstract}

\section{Keywords}

Teenagers, Lambliasis, Cytokines

\section{Introduction}

The long-period persistence of lamblia in a human body shows an adverse effect on immune system and promotes development allergic and autoimmune reactions [1]-[6]. The feature of the immune response at gelminthprotozoal invasions is the weak specificity of immune response caused by heterogeneity of parasitic antigens [2] [4]. "The molecular mimicry" is widespread among parasites when the molecular structure of the fibers of parasite reproduces the structure of number of immune-regulatory fibers of the owner [3] [5]. Some individuals use the cytokines of the owner as the growth factors [7] [8]. All these "strategies" of counteraction to immune sys- 
tem of a person allow parasites to survive in the organism of owner [9].

Object of Research: to estimate the level of cytokines at teenagers suffering from lambliasis.

\section{Materials and Methods}

According to the object of research the teenagers, their parents and teachers have consented to participate in the inspection which corresponded to the ethical standards developed in compliance with the declaration of Helsinki. Inspected were altogether 408 children-teenagers in age from 15 till 18 years old (232 girls and 176 boys) in Novosibirsk. As a result of inspection were allocated two groups of teenagers: the 1st group-almost healthy, without lambliasis (200 children), the 2nd group-teenagers with confirmed diagnosis_lambliasis (208 children). All groups were comparable on sex and age.

The criterion of research for both groups was age of teenagers, for the 1st group-the absence of lambkiasis, for the 2nd group- teenagers with lambliasis. The diagnosis "lambliasis" has been verified on the basis of the data of scarological researches by duodenal sounding (17 percent), serological blood tests by the method of immune enzymatic analysis.

Criteria of exception of inspection: signs of acute inflammatory process.

Definition of concentration of IL-1 $\beta$, IL-4, IL-6, IL-8, IL-10 was executed using the commercial test-systems (Society of Limited Responsibility "Citokine", St. Peterburg) in compliance with the direction of Producer of Lactoferrin - by means of commercial test-systems of the Producer "Vector-Best". The level of circulating immune complexes in the blood serum was determined by the method of liquid precipitation $4 \%$ PEG (polyethylenglicol)-6000.

The statistical processing of material was carried out using the complex of statistical programs Statistica 6.0 ("Statsoft", USA).

\section{Results of Research}

For studying of features of current lambliasis invasia at teenagers of the 2nd group were analyzed: the data of anamnesis, complaints of patients, presence of factors of hereditary predisposition, the clinical pattern of disease.

The chronic current of lambliasis was observed at teenagers of the 2nd group (93 percent) and was shown in the form of intestinal, hepatobiliary, astenoneurotic, toxic-allergic, anaemic, rheumatoid and the mixed forms. At a part of teenagers the lambliasis was declared without evident clinical manifestations (7\%).

The immune response of an organism on lambliasis invasia may be various both quantitatively and qualitative, depending on the type of lamblia. The incomplete immune answer to lamblias may develop. In the condition of the immune insufficiency the unchecked reproduction of lamblias may be developed [1] [9].

The comparison of citokine profile at the surveyed teenagers of both groups is spent. The obtained data are presented in the Table 1.

The researches have shown: at lambliasis the spontaneous reproduction of citokines is increased. The researchers have registered the statistically significant hypercitokinemia at the expense of pro-inflammatory and anti-inflammatory citokines, with the maximum concentration of IL- $1 \beta$ and IL-4.

Table 1. The content of cytokines IL-10, IL-1 $\beta$, IL-4, IL-6, IL-8, lactoferrin, autoantibodies (AAB), CEC, antigens $(\mathrm{AG})$, circulating immune complexes $(\mathrm{CIC})$ and DNA in the blood serum of the inspected teenagers $(\mathrm{M} \pm \mathrm{m})$.

\begin{tabular}{cccc}
\hline Factors & 1st group (without lambliasis) & 2nd group (with lambliasis) & P (validity) \\
\cline { 2 - 4 } & 1st group $\mathrm{n}=200$ & 2nd group $\mathrm{n}=208$ & $<0.05$ \\
\hline IL-10, pg/ml & $18.5 \pm 3.1$ & $38.6 \pm 6.2$ & $<0.05$ \\
IL-1 $\beta, \mathrm{pg} / \mathrm{ml}$ & $16.2 \pm 3.0$ & $57.9 \pm 6.7$ & $<0.05$ \\
IL-6, pg/ml & $16.1 \pm 4.2$ & $47.2 \pm 4.3$ & $<0.05$ \\
IL-8, pg/ml & $22.1 \pm 3.3$ & $42.9 \pm 3.9$ & $<0.05$ \\
IL-4, pg/ml & $18.2 \pm 3.4$ & $82.2 \pm 8.4$ & $<0.05$ \\
CEC (in standard units) & $50.8 \pm 5.9$ & $118.6 \pm 13.3$ & $<0.05$ \\
Lactoferrin, ng/ml & $546.0 \pm 43.0$ & $1178.2 \pm 106.3$ & $<0.05$ \\
AAB to AG and DNA & $30.9 \pm 2.9$ & $87.2 \pm 9.0$ & $<0.05$ \\
\hline
\end{tabular}


It is coordinated with the following data: the IL- $1 \beta$ may be activated by variety of biologically active substances, with initiation of the protective reactions' complex (the response of acute-phase), nevertheless, the main and the most powerful activator of this process are components of cellular walls of parasites. Besides, the parasites and their derivatives can directly or non-directly influence on the citokines' cascade, repeatedly increasing reproduction of ambivalent cytokines [7] [8].

Individually the content of the regulator of the immune inflammation (IL-8) in the blood serum at teenagers of the 2nd group has been raised in 1.9 - 4 times.

Indicative was the monitoring of one of early mediators of "before-immune" inflammations-hemoattractant, which induces the expression of adhesion molecules, IL-8.

Individually the reproduction of IL-8 authentically increased at patients with lambliasis in comparison with the norm in 1.5 - 2 times, the synthesis of IL-4 which suppresses the production of hemokine is also increased in 3 - 6 times. The IL-1 $\beta$, IL-6, IL-81 $\beta$ are collected in blood at inflammatory process against the background of lambliasis invasia and adequately reflected the severity of its course.

Thus, pathological activation of phagocytes and other immunocytes, which is revealed, in particular, in the high production of acute-phase cytokines IL- $1 \beta$, IL-8 is directed on the maintenance of damaging, rather than of repairing mechanisms of the immune response.

The levels of the opposite cytokines IL- $1 \beta$ and IL-10, also as the levels of IL-8 and IL-4 demonstrated the equal dynamics. The IL- $1 \beta$ as the strongest inhibitor of IL- 10 was reproduced only in the presence of IL- $1 \beta$.

Fluctuations of indicators of citokines' synthesis at a part of teenagers, apparently, are caused by various severity of infectious process and by presence of combined pathology, and, hence, by different degree of suppression of the immune response.

\section{Conclusion}

The presence of lambliasis invasia was accompanied by constant antigen stimulation with the subsequent development of immune reaction and increase of inflammatory destructive processes in an organism, by increase of synthesis of pro-inflammatory citokines, albumines of acute phase, by occurrence of markers of cellular damage and stimulation of humoral link of immune system.

\section{References}

[1] Bartelt, L.A., Roche, J., Kolling, G., Bolick, D., Noronha, F., Naylor, C., Hoffman, P., Warren, C., Singer, S. and Guerrant, R. (2013) Persistent G. lamblia Impairs Growth in a Murine Malnutrition Model. Journal of Clinical Investigation, 123, 2672-2684. http://dx.doi.org/10.1172/JCI67294

[2] Boef, A.G., May, L., van Bodegom, D., van Lieshout, L., Verweij, J.J., Maier, A.B., Westendorp, R.G. and Eriksson, U.K. (2013) Parasitic Infections and Immune Function: Effect of Helminth Infections in a Malaria Endemic Area. Immunobiology, 218, 706-711. http://dx.doi.org/10.1016/j.imbio.2012.08.273

[3] Frieling, T. (2005) Serum Cytokine Changes in Turkish Children Infected with Giardia lamblia with and without Allergy: Effect of Metronidazole Treatment. Acta Tropica, 95, 116-122. http://dx.doi.org/10.1016/j.actatropica.2005.05.006

[4] Kamda, J.D., Nash, T.E. and Singer, S.M. (2012) Giardia duodenalis: Dendritic Cell Defects in IL-6 Deficient Mice Contribute to Susceptibility to Intestinal Infection. Experimental Parasitology, 130, 288-291. http://dx.doi.org/10.1016/j.exppara.2012.01.003

[5] Maciorkowska, E., Kaczmarski, M. and Kemona, A. (2005) The Role of Cytokines in Giardiasis in Children. Medycyna Wieku Rozwojowego, 9, 665-673.

[6] Mahmoud, M.S., Salem, A.A. and Rifaat, M.M. (2004) Human Giardiasis as an Etiology of Skin Allergy: The Role of Adhesion Molecules and Interleukin-6. Journal of the Egyptian Society of Parasitology, 34, 723-737.

[7] Matowicka-Karna, J., Dymicka-Piekarska, V. and Kemona, H. (2009) IFN-gamma, IL-5, IL-6 and IgE in Patients Infected with Giardia intestinalis. Folia Histochemica et Cytobiologica, 47, 93-97. http://dx.doi.org/10.2478/v10042-009-0013-3

[8] Matowicka-Karna, J., Kralisz, M. and Kemona, H. (2011) Assessment of the Levels of Nitric Oxide (NO) and Cytokines (IL-5, IL-6, IL-13, TNF, IFN-gamma) in Giardiosis. Folia Histochemica et Cytobiologica, 49, 280-284. http://dx.doi.org/10.5603/FHC.2011.0039

[9] Jimenez, J.C., Fontaine, J., Grzych, J.M., Capron, M. and Dei-Cas, E. (2009) Antibody and Cytokine Responses in BALB/c Mice Immunized with the Excreted/Secreted Proteins of Giardia intestinalis: The Role of Cysteine Proteases. Annals of Tropical Medicine and Parasitology, 103, 693-703. http://dx.doi.org/10.1179/000349809X12502035776351 